tów obecnych wedle didaskaliów na scenie - kapeli góralskiej z drumlą, piszczałkami, trąbą i bębnem (s. 130) czy grających marsza weselnego dud (s. 93).

W zakreślonych sobie granicach „czysto muzycznej” edycji praca Kukli wypada bardzo korzystnie - ze wskazanymi wyżej zastrzeżeniami, faktycznie marginalnymi, choć fatalną mocą specyfiki tekstu recenzyjnego wyrosłymi tu na plan pierwszy. Niemniej, zasadne pozostaje pytanie, czy edycja dzieła operowego (i to o takiej randze) nie winna spełniać bardziej interdyscyplinarnych wymagań. Choć nie ulega wątpliwości, iż muzyczny współczynnik dzieła przekazany został odbiorcy kompetentnie i wiarygodnie, wymowa autograficznej partytury jako dokumentu literackiego i teatralnego pozostaje jednak w dużej mierze wciąż jeszcze do odczytania.

Jakub Chachulski

Instytut Sztuki, Polska Akademia Nauk

\title{
JÓZEF ELSNER, KRÓL ŁOKIETEK, CZYLI WIŚLICZANKI. OPERA W DWÓCH AKTACH. LIBRETTO LUDWIK ADAM DMUSZEWSKI, WYD. GRZEGORZ ZIEZIULA
}

Warszawa 2019 (= Monumenta Musicae in Polonia. Seria E: Opera selecta)

Instytut Sztuki PAN, ss. 527. ISBN 978-83-65630-84-I

$\mathrm{O}_{\mathrm{s}}^{\mathrm{d}}$ d czasu wydania w 1957 r. monografii Józefa Elsnera autorstwa Aliny Nowak-Romanowicz i opracowań na jego temat opublikowanych w 2013 r. (m.in. praca zbiorowa pod red. Remigiusza Pośpiecha) objaśnione zostały szczegóły jego biografii i główne nurty wielorakiej aktywności muzycznej; opisano przede wszystkim utwory religijne, lecz nie dokonano pogłębionej i kontekstowej prezentacji pozostałej twórczości kompozytora, a zwłaszcza obfitej i różnorodnej pod względem gatunkowym muzyki scenicznej. W kilku artykułach problematykę pojedynczych utworów tego typu poruszali: Danuta Idaszak (I980), Alina Żórawska-Witkowska (2005), Jakub Chachulski (2019), Michał Jagosz (2020) ${ }^{\mathrm{I}}$.

I Zob.: Danuta Idaszak, „Wąwozy Sierra Morena - opera Józefa Elsnera ze zbioru florenckiego", Pagine 4 (1980), s. 309-323; Alina Źórawska-Witkowska, „Historia w operze, czyli postacie władców w operach Jadwiga, królowa polska Karola Kurpińskiego (I8I4) oraz Król Eokietek Józefa Elsnera (I8I8)", Muzyka 50 (2005) nr 3, s. 57-88; Jakub Chachulski, „Fragment zagi-
Podjęcie się wieloaspektowej charakterystyki wszystkich dzieł muzycznych Elsnera oraz włączenie ich do repertuaru aktualnych i historycznie kompetentnych praktyk muzycznych umożliwia bowiem przede wszystkim systematyczna praca badawczo-edytorska finalizowana źródłowo-krytycznymi wydaniami partytur jego dzieł. Takie kroki w polskiej muzykologii zostały już poczynione. Od 2006 r., od opublikowania partytury Nieszporów Elsnera przez Polskie Wydawnictwo Muzyczne w serii Muzyka Jasnogórska. Musica Claramontana ${ }^{2}$, ukazały się

nionego singspielu Józefa Elsnera”, Muzyka 64 (2019) nr 3, s. 99-IO9; Jakub Chachulski, „"Zły smak i gminna przesada». Kilka uwag o muzyczno-dramatycznej konstrukcji opery Suttan Wampum Józefa Elsnera na tle oryginalnego libretta Augusta von Kotzebue”, Muzyka 64 (2019) nr 4, s. 3-36; Michał Jagosz, „Odpis hymnu Nurakina «O ty! Co równie znędzniałym» $\mathrm{z}$ melodramatu Iskahar, król Guaxary Józefa Elsnera odnaleziony w zbiorach Biblioteki Jagiellońskiej", Muzyka 65 (2020) nr I, s. II9-I25.

2 Kraków 2006, wyd. Hubert Prochota. 
Deux Polonaises à grand orchestre w Wydawnictwie Horizon ${ }^{3}$, natomiast w 1. 2016-I9 pięć tomów edycji Instytutu Sztuki PAN Monumenta Musicae in Polonia, serii E: Opera selecta. Obejmują one utwory fortepianowe, msze (łacińskie i polskie), pieśni i katalog tematyczny 4 oraz recenzowanego tu Króla Eokietka.

Nazwisko Józefa Elsnera (I769-I854) za jego życia i dość długo po śmierci, co najmniej do przełomu XIX i XX w., było kojarzone z muzyką sceniczną. W okresie zaraz po II wojnie światowej był natomiast rozpoznawalny przede wszystkim jako nauczyciel Fryderyka Chopina, w mniejszym stopniu innych polskich kompozytorów urodzonych między I800 a I8I6 rokiem. Cechą znamienną ich wszystkich, poza Ignacym Feliksem Dobrzyńskim, jest to, że oni - Józef Nowakowski, Józef Krogulski, Edward Wolff - nie spełnili życzenia swojego pedagoga, które być może wysunął nie tylko wobec Chopina. Sam nauczyciel miał przecież na polu teatralno-operowym duże doświadczenie technicznokompozytorskie, praktyczno-dyrygenckie i organizacyjne, uzyskane w 1. I79I-I824. Może uczniowie w niewielkim stopniu znali różnorodną muzykę sceniczną swojego mistrza, a może on w trakcie lekcji nie podejmował kwestii dotyczących takiej twórczości. Tego rodzaju pytania nasuwają się wprost, zwłaszcza obecnie, kiedy na podstawie wydanego w 2019 r. i opracowanego przez Jakuba Chachulskiego drugiego tomu katalogu tematycznego utworów

3 Kraków 20I4, wyd. Mirosław Płoski.

4 Józef Elsner, Utwory fortepianowe / Piano Work, wyd. / ed. Jerzy Morawski, Warszawa 2or6; Józef Elsner, Msze op. 26, 35, 42, 62, $75 /$ Masses Opp. 26, 35, 42, 62, 75, wyd. I ed. Jadwiga Jasińska, Warszawa 2017; Józef Elsner, Pieśni / Songs, wyd. / ed. Małgorzata Sieradz, Tomasz Chachulski, Warszawa 20I8; Józef Elsner, Katalog tematyczny utworów / A Thematic Catalogue of the Works, cz. / part II: Utwory świeckie / Secular Music, przygotował / prepared by Jakub Chachulski, Warszawa 2019.
Józefa Elsnera wiemy, że jego dorobek w zakresie autonomicznych dzieł operowych był duży. Obejmuje trzydzieści sześć dzieł, z których dziesięć zachowało się w pełnej postaci, pięć tylko z przekazem partii muzycznej, sześć we fragmentach, lecz dotychczas żadne $\mathrm{z}$ nich nie zostało w całości i w wersji wokalno-orkiestrowej wydane. Po dwustu latach od premiery jednego $\mathrm{z}$ takich utworów Elsnera pionierskiego zadania odważnie podjął się Grzegorz Zieziula. Odwagi dodawało mu z pewnością doświadczenie wyniesione $\mathrm{z}$ pracy nad literackim i muzycznym materiałem do wydania partytury Goplany Żeleńskiego, zwieńczonej naukowo -edytorskim sukcesem w 2016 roku.

W ramach wspomnianej źródłowo-krytycznej serii edytorskiej IS PAN (red. naczelna Barbara Przybyszewska-Jarmińska), jakże istotnej dla poznania historii muzyki polskiej, Grzegorz Zieziula przygotował wydanie opery Józefa Elsnera pt. Król Łokietek, czyli Wiśliczanki z librettem Ludwika Adama Dmuszewskiego, której prapremiera odbyła się 3 IV I8I8 r. w Teatrze Narodowym w Warszawie. Pierwodruk wyłącznie libretta ukazał się w I82I r. we Wrocławiu. Już przytoczone powyżej fakty są przesłanką na rzecz doniosłości recenzowanego dokonania wydawniczego. Pozostałe, i moim zdaniem najważniejsze, argumenty za wysoką wartością edycji przedstawiam poniżej.

Wydanie pełnej partytury Króla Eokiet$k a$, w porównaniu $\mathrm{z}$ analogicznymi zadaniami w odniesieniu do innych polskich oper z XIX w., nastręczało szczególne trudności. Wymagało, jak określił swój cel badawczo-edytorski Zieziula, „scalenia w jedną spójną całość muzyki i współczynnika literackiego $\mathrm{w}$ jego postaci integralnej (wraz z tzw. tekstem mówionym i obszernymi didaskaliami nieobecnymi w rękopisie partytury)" (s. 40). Do 2019 r. taka forma wokalno-słowno-instrumentalnej partytury nie istniała.

Poza, rzec można, standardową koniecznością zgromadzenia i krytyki rozproszonych źródeł muzycznych i literackich, nie- 
odzowne było dokonanie wnikliwej analizy filologicznej zachowanych testów - muzycznego i słownego, co wydawca pieczołowicie uczynił. W sumie krytyczne omówienie objęło w zakresie źródeł muzycznych jedno podstawowe (autograf), sześć pomocniczych i trzy przekazy o drugorzędnym znaczeniu, natomiast $\mathrm{w}$ stosunku do libretta - jedno źródło podstawowe (pierwodruk), trzy pomocnicze i jedno drugorzędne. Źródła zostały dobrze zhierarchizowane i szczegółowo scharakteryzowane pod względem ich cech fizycznych i treściowych, z uwzględnieniem m.in. kwestii datowania, dedykacji, proweniencji, ich aktualnej lokalizacji, określenia stopnia przydatności dla rekonstrukcji zapisu partyturowego utworu wodewilowego.

Rzeczowe i prawidłowe wnioski wyciągnięte $\mathrm{z}$ tych różnego typu analiz rozmaitego rodzaju przekazów (co poświadczają poza cechami edycji partytury m.in. komentarz krytyczny i wykaz korektur), nie mogły być jednak wystarczające, aby urzeczywistnić założone scalenie partytury. Faktycznie pomocną okazała się również skrupulatna analiza sposobu ukształtowania przebiegu dramaturgiczno-muzycznego opery, funkcji czynnika tanecznego, koncepcji całości formalnych - instrumentalno-wokalnych czy ponadto pantomimiczno-baletowych, których schematy poglądowe ujęte w tabelach zamieścił Zieziula w komentarzu krytycznym (s. 478, 489). Unaoczniają one i jednocześnie wspierają jego decyzje edytorskie, a zarazem wraz $\mathrm{z}$ informacjami podanymi we wstępie oraz $\mathrm{w}$ streszczeniu libretta są cennym objaśnieniem warsztatu kompozytorskiego Elsnera.

Trzeba podkreślić, że analiza różnych aspektów dramaturgiczno-muzycznych i owych form została ugruntowana w wiedzy o gatunkach muzyki scenicznej XVIII-XIX w., związaną $\mathrm{z}$ tym terminologią, a przede wszystkim oparta na znajomości specyfiki wodewilu i wyczuleniu na płynność używanych przez kompozytorów, pisarzy i instytucje teatralne określeń: opera (seria, buffa, mezzo stilo), singspiel, komedioopera, operetka. Ponadto wydawca sprecyzował inne terminy, które odnosi do elementów elsnerowskiego wodewilu: chór baletowy/wodewilowy choeur dansés, dialogi mówionel dialogues parlés. Zieziula jako pierwszy w historiografii muzyczno-teatralnej proponuje rzeczowe, przekonujące objaśnienie cech gatunkowych dzieła Elsnera-Dmuszewskiego jako utworu wodewilowego, nie pomijając kwestii mieszania przez twórców konwencji wodewilowej z operową.

W postępowaniu badawczo-edycyjnym okazało się jednak, że mimo poczynienia opisanych już przeze mnie „milowych” kroków dopiero pogłębiony namysł zarówno nad wystawienniczymi praktykami teatralno-operowymi epoki Elsnera, jak i zwyczajami oraz rzeczywistymi możliwościami niektórych scen teatralnych mógł przynieść istotne wskazówki, lub związane $\mathrm{z}$ nimi hipotezy umożliwiające stworzenie partyturowej jedni. Ślady praktyk teatralnych lub transkrypcyjnych figurują m.in. w pierwodruku libretta, na jego rękopiśmiennym egzemplarzu suflerskim z ok. I873 r., na rękopiśmiennym wyciągu fortepianowym (półautograf) z lat czterdziestych/ pięćdziesiątych XIX wieku. Pewne drobne przesłanki dla rozwiązań interpretacyjnych istniejące w przekazach prasowych na temat scenicznych realizacji Wiśliczanek w polskich teatrach w XIX w., wykorzystane w mniejszym stopniu. Moim zdaniem, oryginalność recenzowanej koncepcji edytorskiej opery Elsnera-Dmuszewskiego polega właśnie na potraktowaniu wszystkich historycznych przekazów muzycznych, literackich i piśmienniczych, jako dokumentów społecznego „życia” tego wodewilowego dzieła.

Bez wątpienia, ważnym składnikiem dokonanej przez Grzegorza Zieziulę charakterystyki cech Króla Eokietka jest podjęcie kwestii posłużenia się przez Elsnera w obydwu aktach cytatami - autocytatami i z dzieł innych autorów, czy użyciem znanej pieśni 
kościelnej oraz narodowej (wszystkie zidentyfikowane, s. I3, 489) - problematyki ujętej w perspektywie logiki muzyczno-teatralnej, z odczytaniem konotacji semantycznych i symbolicznych w scenie "Snu Hinkona”. Nie zostało też pominięte zagadnienie stylizacji gwarowych i archaizacji obecnych w libretcie, co prawda niezbyt licznych, lecz współtworzących „ludową” aurę wodewilu. Historia opowiedziana w treści utworu, postacie polskich królów, udział ludu, orszaki bohaterów Rzeczpospolitej, zasłużonych literatów i uczonych oraz znaczny udział w muzyce dzieła Elsnera-Dmuszewskiego „narodowych” tańców i rytmów tanecznych krakowiaka, mazura, poloneza, to czynniki dobrze scharakteryzowane przez autora opracowania. Po lekturze jego analiz, komentarzy i odczytaniu dzisiaj tekstu samej partytury, nie mamy wahań, aby w pełni przyznać muzykologowi rację, że - jak sam napisał we wstępie - „w dziejach polskiej twórczości operowej Król Łokietek odegrał doniosłą rolę, co więcej, że w I połowie XIX w. stał się wzorcem opery narodowej" (s. I2). $\mathrm{Na}$ rzecz akceptacji takiego poglądu przemawiają również sposoby odczytania tego utworu, przejawiające się w dziewiętnastowiecznej praktyce teatralnej przez wprowadzanie do jego poszczególnych realizacji tzw. żywych obrazów, które intensywnie wzmagały wymowę narodowo-patriotyczną wodewilowych spektakli.

W zakresie recepcyjnego pola Króla Łokietka kieruję do Grzegorza Zieziuli kilka drobnych uwag lub pytań czy uzupełnień.

Myślę, że współcześni nam miłośnicy twórczości Niccola Paganiniego i jego popularnej Sonaty „Varsavia” z wdzięcznością przyjmą odesłanie do niej, jako przykładu recepcji polskiej narodowej opery Król Łokietek. Włoski wirtuoz użył bowiem tematu mazurka Parobcaki od Potańca z jej drugiego aktu. Szkoda jednak, że kompetentny wydawca opery Elsnera, stwierdzając, że w czasie koncertów Paganiniego w Warszawie od maja do I4 VII I829 r. opera ta od dawna nie była już grana, nie postawił hipotezy, za jakim osobowym i/lub partyturowo-transkrypcyjnym pośrednictwem mógł się zapoznać z melodią Parobcaków sławny genueńczyk.

$\mathrm{Na}$ poplecznika swojej tezy o wzorcu opery narodowej, uobecnionym w wydanej operze Elsnera, wybrał Grzegorz Zieziula innego ze swoich ulubieńców, dobrze mu znanego Władysława Żeleńskiego. Oczywiście, to historyczny autorytet, ale cytując jego opinię za pracą Józefa Reissa z 1936 r., współczesny nam badacz nie poszukał jej pierwotnego źródła, nie określił roku i okoliczności jej sformułowania. Nie znalazłam również informacji i w konsekwencji też wyjaśnienia, dlaczego $\mathrm{w}$ anonsach niektórych scenicznych realizacji opery Elsnera, np. we Lwowie (1845, I862, I894) i Krakowie (I863-64, I866, I873-75, I877) podawano, że jest to „opera w 3 aktach” a nie w dwóch (Lwów I825, Kraków I820, Warszawa I831)5. Takie rozbieżne informacje figurują przecież nawet na afiszach reprodukowanych w wydanej partyturze jako materiał ilustracyjny.

Wartym odnotowania jest pojawiający się od lat sześćdziesiątych XIX w. casus podkreślania w anonsach i afiszach spektakli Króla Łokietka np. w Krakowie (1863, I864, I866, I877) i Lwowie (I894), że jest to „opera narodowa”. Ważna ze względu na kontekst historyczny i wymowę symboliczną przedstawień Wiśliczanek byłaby, moim zdaniem, odpowiedź na pytanie, kiedy rozpoczął się zwyczaj włączania doń żywych obrazów. Mogę jednak wskazać więcej, poza jednym przytoczonym przez Zieziulę, przykładów

5 Zob. w partyturze ilustracje nr 4-8. Por. anonse i recenzje w: Gazeta Krakowska 27 (I820) nr 77 z 24 IX, s. I2, nr 78 z 27 IX, s. I2, nr 82 z II X, s. I2; Czas I6 (I863) nr 6I z I5 III, s. 4, nr 95 z 26 IV, s. 4, I9 (I866) nr 54 z 6 III, s. 4, 27 (I874) nr 79 z 8 IV, s. I, 30 (I877) nr 293 z 25 XII, s. 2, 46 (I893) nr 294 z 23 XII, s. I; Chwila 2 (I864) nr 54 z 6 III, s. 4; Gazeta Lwowska 84 (I894) nr 73 z 3I III, s. 4; Dziennik Polski 27 (I894) nr 90 z I IV, s. 3; Gazeta Narodowa 34 (1894) nr 74 z I IV, s. 3. 
tematyki i wzorców żywych obrazów z realizacji wodewilu Elsnera w latach siedemdziesiątych XIX w. w obu wspomnianych miastach. Były bowiem wśród nich realizacje przygotowane według znanych powszechnie, zwłaszcza w okresie zaborów, dzieł malarskich. Do takich należały płótna pędzla Jana Matejki: Unia Lubelska z I869 r., według której ułożono żywy obraz w spektaklu Króla Eokietka w Krakowie w I873 r., Stefan Batory pod Pskowem - obraz olejny z I872 r., jaki prawdopodobnie inspirował realizację lwowską w I874 r., oraz Zawieszenie dzwonu Zygmunta na wieży Katedry w Krakowie w IS2I roku namalowane w I874 r., będący inspiracją dla żywego krakowskiego obrazu w przedstawieniu w I875 r. ${ }^{6}$. Pamiętajmy, że te trzy dzieła Matejki zaraz po ich powstaniu były publicznie eksponowane w Krakowie i Lwowie (ponadto w Wiedniu, Paryżu, Londynie), a ich patriotyczna wymowa szeroko dyskutowana.

Z kolei obraz Bitwa pod Ractawicami, pochodzący z I862 r., był autorstwa Walerego Eliasza-Radzikowskiego - malarza, grafika i scenografa doskonale rozpoznawanego w Krakowie jako piewca kościuszkowskiej wielkości. Dzieło to stanowiło podstawę zastygłych rekonstrukcji konfiguracji bitewnych w operze w inscenizacjach z roku 1874 i $1875^{7}$. Przygnębiające, lecz sugestywne ukazanie przez Artura Grottgera pochodu

6 „Przegląd dramatyczny [recenzja ze spektaklu 2I XII I873]”, Czas 26 (I873) nr 294 z 23 XII, s. I; „[Afisz przedstawienia w Teatrze Krakowskim 2I XII I873]", Afisz Teatralny 3 (I873) nr 48, s. [2]; „Kronika [Lwów, przedstawienie 22 II I874], $G a$ zeta Narodowa I4 (I874) nr 43 z 22 II, s. 2; „Teatr [uwagi na temat spektaklu 29 III I875], Czas 28 (I875) nr 74 z I IV, s. 2; zob. też: „Kronika. Opera [reakcja publiczności na przedstawieniu we Lwowie 22 II I874], Gazeta Narodowa I4 (1874) nr 44 z 23 II, s. 3.

7 „Kronika miejscowa i zagraniczna”, Czas 27 (I874) nr 77 z 4 IV, s. 2; „Teatr”, Czas 27 (I874) nr 78 z 5 IV, s. 3; „[Afisz przedstawienia w Teatrze Krakowskim 29 III I875]”, Afisz Teatralny 5 (I875) nr 40, s. [2]. zesłańców na Sybir, na rysunku z I866 r., zostało rozpowszechnione za pomocą kartki pocztowej, będącej litograficzną odbitką fotografii tego rysunku, wykonanej przez krakowskiego fotografa Awita Szuberta, a wydanej przez Księgarnię i Skład Nut Gubrynowicz i Schmidt we Lwowie. Była ona m.in. rozdawana jako premia za rok 1870 dla członków Towarzystwa Przyjaciół Sztuk Pięknych w Krakowie, nic więc dziwnego, że Pochód na Sybir posłużył za pierwowzór żywego obrazu w I874 roku.

Jako mieszkanka grodu pod Wawelem, gdzie zawsze miano sentyment do pochodu królów - realnie odtwarzanego lub zadomowionego w wyobraźni - nie mogę pominąć odnotowania jego okazałej obecności w tutejszych wystawieniach elsnerowskiej opery. Muszę wyliczyć, choć długi, skład takiego orszaku królów i pozostałych ważnych dla Polaków historycznych osobistości, nie tylko wzmiankowanych w libretcie, które doskonale ucharakteryzowane, jak zapewniali sprawozdawcy, dostojnie przemaszerowały przez scenę w grudniu I873 r. w następującej kolejności: Kazimierz Wielki, Jadwiga, Jagiełło, Zygmunt Stary, Zygmunt August, Władysław IV, Stefan Batory i Sobieski; Ostrogski, Tarnowski, Zamoyski, Żółkiewski, Czarniecki, Stanisław Rewera Potocki, Kościuszko i Dąbrowski; Rey, Kochanowski, Wacław Potocki, Klonowic, Kniaźnin, Trembecki, Krasicki, Antoni Malczewski, Mickiewicz, Słowacki i $\mathrm{Pol}^{8}$. W jakim stopniu tradycje i lokalny patriotyzm krakowski odcisnęły piętno na publicystycznej recepcji Króla Łokietka, czyli Wiśliczanek świadczy nawet pomyłka popełniona przez redakcję Afisza Teatralnego, która właśnie po entuzjastycznej, adekwatnej do narodowych treści reakcji publiczności i takiej też recenzji spektaklu w I873 r. dodała znamienną informację. Ponoć pochodziła od osób, które pamiętały pierwszy w ogóle pokaz utwo-

8 „Przegląd dramatyczny [recenzja ze spektaklu 2I XII I873]”, Czas 26 (I873) nr 294 Z 23 XII, s. I. 
ru Elsnera-Dmuszewskiego w Krakowie i twierdziły, że odbył się w dniu, kiedy rozpoczęto tutaj sypanie Kopca Kościuszki ${ }^{9}$. To nic, że w I873 r. pomylono obydwie daty, cel medialnego uwypuklenia patriotycznej wymowy obydwu zbiorowych przedsięwzięć został osiągnięty. De facto pierwsze przedstawienie tego wodewilu w Krakowie, w wykonaniu zespołu lwowskiego, miało miejsce 24 IX I820 r., a kopiec zaczęto uroczyście sypać $\mathrm{I} 6 \mathrm{X}$ tegoż roku, natomiast w przeddzień i zarazem w trzecią rocznicę śmierci Kościuszki, I5 X I820 r., odbył się czwarty wówczas spektakl Wiśliczanek ${ }^{\mathrm{r}}$.

Minęło ponad pięćdziesiąt lat i 23 XII I873 r. napisano: „Po niedzielnym przedstawieniu [2I XII] przekonani jesteśmy, że Wiśliczanki drogocennym są dla naszego [krakowskiego teatru i jego] repertuaru nabytkiem i że nieraz w niedziele i święto będą przedstawione. Obok melodyjnej muzyki, sztuka ta jest niejako plastycznym streszczeniem dziejów ojczystych, co wielce podnosi jej znaczenie, wartość i praktyczną doniosłość" "II.

Reasumując, wzorcowe opracowanie pierwszego wydania w 2019 r. opery Józefa Elsnera, zgodne z zasadami obowiązującymi we współczesnych edycjach źródłowo-krytycznych, świadczy o interdyscyplinarnych kompetencjach Grzegorza Zieziuli, sprawnym posługiwaniu się metodami i technikami badawczymi muzykologa, historyka literatury, teatrologa, kulturoznawcy. Całkowite zrealizowanie celu badawczo-edytorskiego jest wynikiem przeprowadzenia wnikliwej, wieloaspektowej krytycznej analizy porównawczej i kontekstowej historycznych tekstów muzycznych i literackich, zawierających liczne luki i niedookreślenia, oraz zasadnej rewizji dotychczasowych ustaleń muzykologów. Prezentowane tu wydanie partytury Król Eokietek, czyli Wiśliczanki, jest przedsięwzięciem nowatorskim $\mathrm{w}$ istotnym stopniu poszerzającym wiedzę o polskiej twórczości operowej w XIX w. i randze dokonań Józefa Elsnera. Dzięki wysoce kompetentnej publikacji scalonego tekstu partytury dzieła słowno-muzycznego i dwujęzycznej, polskiej i angielskiej, wersji jego synopsisu, wstępu, opisu źródeł, zasad edytorskich i komentarza krytycznego staje się możliwe wprowadzenie wiedzy o polskim dziele i jego samego do międzynarodowego obiegu naukowego i repertuaru scen operowych. Potencjał aplikacyjny opiniowanej edycji jest niezaprzeczalny, notabene pierwsze jego urzeczywistnienie miało już miejsce. To koncertowe wykonanie i nagranie opery Elsnera-Dmuszewskiego w Filharmonii im. Stanisława Moniuszki w Koszalinie, 29 XI 2019 r. zrealizowane przez solistów (Agnieszka Kozłowska, Aneta Łukaszewicz, Tomasz Krzysica, Jarosław Bręk), chór i Orkiestrę Fundacji Akademia Muzyki Dawnej pod dyrekcją Pawła Osuchowskiego. Publikacja opery Józefa Elsnera ze względu na swe walory naukowe i materiałowo-dokumentacyjne może być nie tylko przedmiotem lektury naukowców reprezentujących nauki o sztuce, lecz także pomocą w dydaktyce uniwersyteckiej (muzykologia, teatrologia, kulturologia) oraz w ramach muzycznych i teatralnych uczelni wyższych.

Matgorzata Woźna-Stankiewicz Uniwersytet Jagielloński
9 Afisz Teatralny 3 (I873) nr 49, s. [I].

Io „Teatr Narodowy”, Gazeta Krakowska 27 (I820)

nr 82 z II X, s. I2.

II Afisz Teatralny 3 (I873) nr 49, s. [I]. 